\title{
Vegetative Status in Patients with Transient Ischemic Attack and Stroke
}

\author{
N. V. Halinouskaya* \\ S. V. Samsonau $* *$ \\ ${ }^{*}$ Gomel State Medical University, \\ Belarus \\ $* *$ Princeton International School \\ of Mathematics and Science, USA
}

\begin{abstract}
Summary. Background. Presented work aims to study the status of the autonomic nervous system (ANS) in two groups of patients during 10-day acute period. One group consists of patients with transient ischemic attack (TIA) and another group consists of patients with stroke. The latter group includes patients with various size of stroke.

Prospective cohort study was carried out in the Department of Neurology and Neurosurgery of the Gomel State Medical University, Stroke Unit of the Gomel Regional Veterans Hospital, between May 2014 and March 2016. The groups included in the study were composed as follows: TIA group contained 13 patients and Stroke group contained 84 patients, including 61 with size of stroke lower than $15 \mathrm{~mm}$ (lacunar stroke - LS) and 23 with size of stroke bigger than $15 \mathrm{~mm}$ (total stroke - TS). Heart rate variability (HRV) was used to describe status of the ANS. It was measured at the $1^{\text {st }}$ and $10^{\text {th }}$ day of staying in the hospital. Obtained HRV records were analyzed using the following four parameters: SDNN (standard deviation of the normal-to-normal $\mathrm{R}-\mathrm{R}$ intervals, in $\mathrm{ms}$ ), $\Delta \mathrm{X}$ (the difference between maximal and minimal R-R interval, in ms), Mo (mode of the duration of R-R intervals, in ms), AMo (amplitude of the R-R intervals mode, in percent).

Results. For the HRV taken on the $1^{\text {st }}$ day of admission, the dependence between $\Delta \mathrm{X}$ (representing activity of parasympathetic part of ANS) and Mo (representing sympathetic part of ANS) was found to be significantly different in TIA and TS groups $(\mathrm{p}=0.01)$.

Conclusion. The key difference between TIA and TS is a difference in the relationship between the humoral regulation of the activities of the ANS and the parasympathetic part activity at the $1^{\text {st }}$ day, which determines specific features of pathogenesis of the transient ischemia.
\end{abstract}

Keywords: transient ischemic attack, lacunar stroke, total stroke, sympathetic and parasympathetic parts of autonomic nervous system.

\section{INTRODUCTION}

Stroke is the most often cause of death for people in Europe and US and the first cause of disability in people over the age of $60[1,2]$. Transient ischemic attack (TIA) is a shortterm infringement of brain blood circulation that often precedes the stroke $[1,3]$. TIA patients have a high risk of subsequent stroke: $4-8 \%$ during 1 month and $30 \% 5$ years after TIA $[1,3]$.

\author{
Address: \\ Natallia $V$. Halinouskaya \\ Gomel State Medical University, \\ Lange st. 5, Gomel 246000, Belarus \\ E-mail: stroke.ynt@tut.by
}

Dysfunction of ANS in stroke patients is associated with worse functional outcome and higher mortality rate [4-11]. Hyperactivity of sympathetic part of ANS is the dominant condition of ANS in the main basic prestroke conditions such as atherosclerosis, arterial hypertension, coronary heart disease, chronic kidney disease [12-28]. Hyperactivity of the sympathetic part of the ANS is accompanied by vasospasm, increased blood pressure, hyperglycemia, insulin resistance, increased catecholamine level in blood [23].

Changes in ANS activity in stroke patients are caused by a damage of the suprasegmental part of the brain and an activation of a systemic response to the necrotic focus in the brain $[29,30]$. The direction of the mechanisms of the vegetative regulation with increased activity of the seg-

(C) Neurologijos seminarai, 2018. Open Access. This article is distributed under the terms of the Creative Commons Attribution 4.0 International License CC-BY 4.0 (http://creativecommons.org/licenses/by/4.0/), which permits unrestricted use, distribution, and reproduction in any medium, provided you give appropriate credit to the original author(s) and the source, provide a link to the Creative Commons license, and indicate if changes were made. 
mental apparatus changes during the acute period of stroke [31]. The combination of severe damage of the brain with low heart rate variability (HRV) is a poor prognostic factor for patients survival $[7,8,10,31,32]$, as well as the predictor of development of post-stroke infections [33]. The high activity of the sympathetic part of the ANS and increased catecholamine levels contribute to the development of cardiac complications and increase mortality in stroke patients [7, 8, 29, 33, 34]. The lower HRV is associated with poor recovery of the neurological deficit $[8,31,35]$. Combination of severe stroke process with low HRV is a poor prognostic factor for survival for two periods of observation: 1) period of hospitalization, 2) the first month after stroke [7, 9, 12]. Progressive atherothrombotic stroke is characterized by centralization of vegetative activity of sympathic part of ANS $[4,8,13,31,35]$. Activation of the sympathetic part of the ANS leads to hypercoagulation capacity and high platelet aggregation [36, 37], hyperglycemia [38], increased risk of myocardial infarction, re-stroke, and deep vein thrombosis [39] during the next year, increase in blood-brain barrier permeability, and brain edema [36, 37, 39]. HRV changes are detected in all pathogenic subtypes of stroke [7, 23, 27, 28, 31]. It was demonstrated $[4,5]$ that patients with lacunar stroke (less than $15 \mathrm{~mm}$ - LS) have depression of HRV and activation of ANS [8, 13, 35]. However, therapeutic strategies that could influence this component of brain ischemia are not present, because mechanisms of underlying pathological processes are unclear [11].

The majority of the authors bind a predominance of the activity of the sympathetic part of the ANS with an unfavourable prognosis $[7,8,12,13,35]$. On the other hand, some publications present data, which suggest connection between sympathicotonia and a more favourable prognosis of stroke [35]. This discrepancy can be explained by the inconsistency of the methods used, different duration of the analyzed periods and electrocardiographic studies in different populations of patients [7].

In our previous publications we showed that sympathetic part of the ANS in TIA patients has a maximal activity comparing with different size stroke patients [40-44]. Considering the more favourable outcome and absence of necrosis focus in TIA patients, we can assume that activation of the sympathetic part of ANS in these patients has a sanogenetic character [40-42]. Thus the interpretation of autonomic imbalance in stroke patients is disputable.

According to previously obtained data, status of humoral regulation influences status of ANS and determines distinctive stress-response in patients with stroke and TIA [45]. In particular, TIA groups have the highest AMo values in comparison to the control group [40]. In stroke patients, AMo did not differ from control group and was significantly lower than in the TIA group. $\triangle \mathrm{X}$ detected in TIA and Stroke groups indicated decrease in parasympathetic tone in TIA patients as compared to control group, and in LS group versus TS [40]. Also, it was shown that stroke clinical status depends on activity of sympathetic and parasympathetic parts of ANS in stroke patients [40-44].
Based on the data on the influence of vegetative status on the direction of the first stage of cerebral ischemia [40] and different humoral regulation of ischemic cascade [45], we hypothesized the relationship between the sympathetic (AMo) and parasympathetic $(\Delta \mathrm{X})$ parts of the ANS from the humoral influence on its activity (Mo). We formulated a hypothesis that patients with various stroke size (TS and LS) and TIA would have distinctive dependences for AMo vs Mo, and $\Delta \mathrm{X}$ vs Mo. This would correspond to a difference in pathogenesis of TS, LS, and TIA. In that case, our null hypothesis is the absence of the above-mentioned difference. In order to investigate this hypothesis we designed and performed the study presented below.

\section{MATERIAL AND METHODS}

13 TIA and 84 stroke patients admitted in the Stroke Unit of the Gomel Regional Veteran's Hospital were surveyed from 2014 to 2016. TIA patients ( 8 women and 5 men, mean age $69.2 \pm 3.3$ years; do not have changes on neuroimaging), 61 patients with LS (size of stroke < $15 \mathrm{~mm}$; 31 women and 30 men, mean age $51.8 \pm 2$ years) and 23 patients with stroke more than $15 \mathrm{~mm}$ (TS) (9 women and 14 men, mean age $50.1 \pm 3.5$ years) were observed. All patients belonged to Caucasian race. The neurologic deficit in stroke patients was objectified using stroke scale of the American National Institute of Health (NIHSS) [1]. On the $1^{\text {st }}$ day the estimation by the NIHSS was for LS - $6(4 ; 7)$ for TS - $13(9.5 ; 17)$. Neurological deficit at admission in TIA patients was presented as hemiparesis $38 \%$, asymmetry of nasolabial folds $46 \%$, instability in the Romberg position $31 \%$, asymmetry of tendon reflexes $46 \%$ and Babinski symptom $77 \%$, hypoesthesia $23 \%$, aphasia $23 \%$. TIA patients had the $\mathrm{ABCD}^{2}$ score of $4(4 ; 5)[46,47]$. Co-morbidities in TIA and stroke patients is presented in Table 1.

All groups were examined according to the Protocols of Diagnosis and Treatment approved by the Ministry of Health of Belarus. Exclusion criteria were: severe neurological deficit (score $>20$ according to NIHSS), hemorrhagic stroke or subarachnoid bleeding, persons with acute phase of chronic diseases.

For evaluation of the ANS status in TIA and stroke patients, HRV analysis was performed according to the accepted procedures [48-51]. Registration of HRV parameters was performed using software and hardware complex "FUCUDA Kardio-MAX-7202" on the $1^{\text {st }}$ and $10^{\text {th }}$ day of

Table 1. Co-morbidities in TIA and stroke patients (in \%)

\begin{tabular}{|l|c|c|c||}
\hline Co-morbidity & TIA & LS & TS \\
\hline Hypertension & 85 & 18 & 63 \\
\hline Coronary heart disease & 85 & 16 & 36 \\
\hline Myocardial infarction & - & - & - \\
\hline Diabetes mellitus & 15 & 5 & 4 \\
\hline Chronic cerebral insufficiency & 23 & 7 & - \\
\hline
\end{tabular}



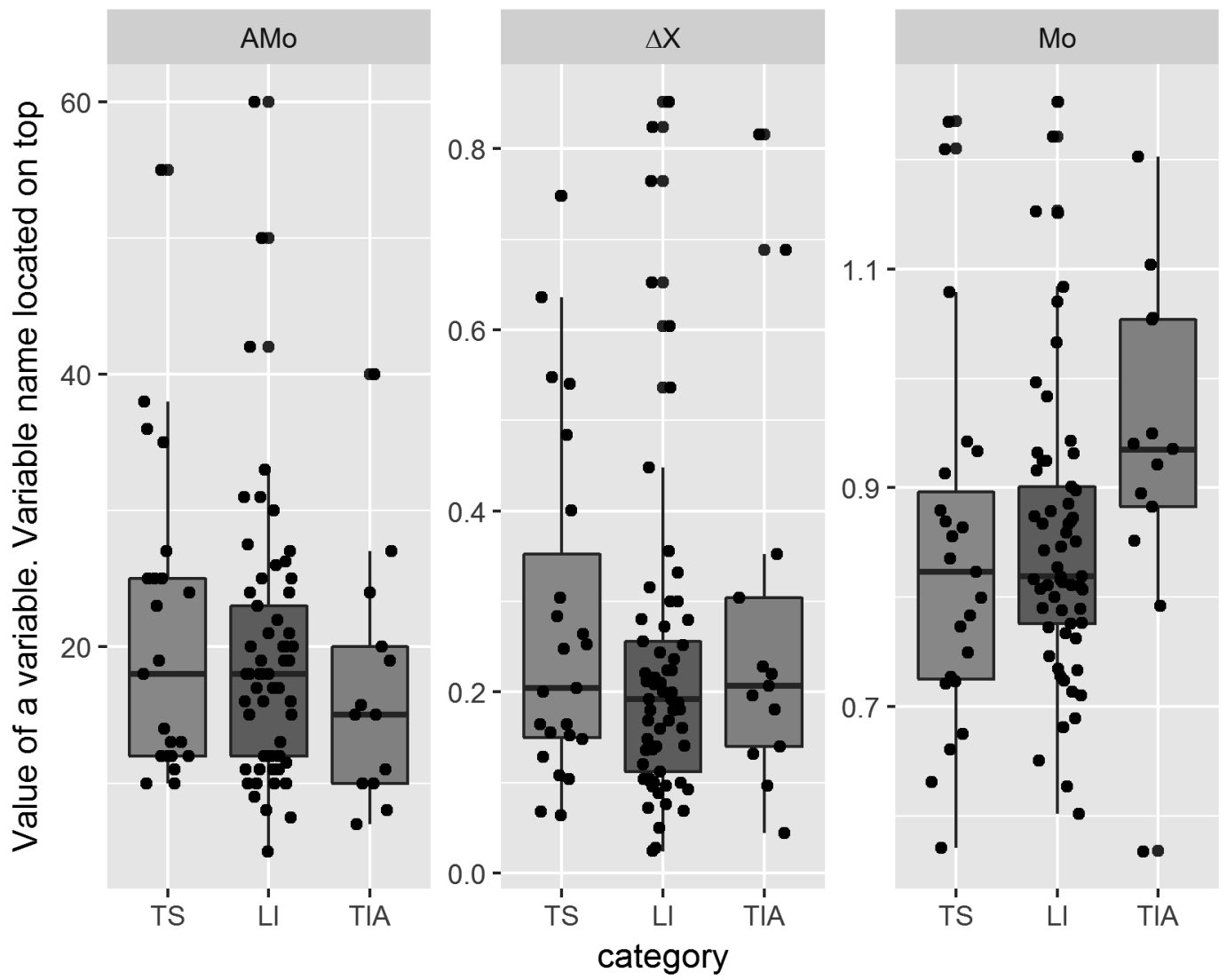

Fig. 1. Box plot for AMo, $\Delta \mathbf{X}$ and Mo values

Separated by categories TS, LI, TIA. Lines inside the boxes represent medians. The lower and upper hinges correspond to the first and third quartiles (the 25th and 75th percentiles). The upper (lower) whisker extends from the hinge to the largest (smallest) value no further than $1.5 \times$ IQR from the hinge (where IQR is the inter-quartile range, or distance between the first and third quartiles). Data beyond the ends of the whiskers are considered to be outliers. Individual observations plotted as black dots.

hospital stay. HRV was assessed in patients after $10 \mathrm{~min}-$ utes of adaptation and 1.5-2 hours after a meal [48-51]. Patients with atrial fibrillation, artificial pacemaker, and patients using $\beta$-blockers were excluded from analysis.

HRV was assessed by calculation of the mean R-R interval and its standard deviation measured on 5 minute electrocardiograms. The following indexes of HRV were calculated: the standard deviation of RR-intervals (SDNN), ms, indicated the general tone of the ANS [48-51]; mode of the duration of R-R intervals, in ms (Mo), ms, indicated the status of functioning sinus node and the degree of humoral influences; amplitude of the $\mathrm{R}-\mathrm{R}$ intervals mode, in percent (AMo), \% - index of activity of sympathetic part ANS, the rigidity HR; variation range $(\Delta \mathrm{X}), \mathrm{c}-$ the difference between the maximum and minimum duration of the RR-interval of the analyzed time series - index activity of the parasympathetic part ANS.

Data were presented as median, lower and upper quartiles. Statistical analysis was performed using $\mathrm{R}$ and several R packages [52-57] (detailed algorithm can be found in the supplemental information). The study was approved by the Ethics committee of Gomel State Medical University. Written informed consents were obtained from the patients (or other approved parties) for the publication of this case report and accompanying images.

\section{RESULTS AND DISCUSSION}

Box plot of the data (Fig. 1) shows a significant number of outliers. Thus, when we are plotting data for exploration purposes (Fig. 2, 3), we use a robust regression (note: no statistical conclusions are based on the visualization). For robust regression, we choose $\mathrm{M}$-estimator instead of generally preferred MM-estimator due to the fact that MM-estimator has trouble with high leverage outliers in small to moderate dimension data [58].

We are comparing 3 correlations for each of two cases: 'AMo vs Mo' and ' $\Delta \mathrm{X}$ vs Mo'. First, we will figure out whether either of these cases has a significant difference in correlations. In order to do this we will obtain $\mathrm{H}$ statistics for a group of independent correlations described in [59].

$$
H=T_{2}-\frac{T_{1}^{2}}{N}=\sum\left(n_{i}-3\right) z_{1}^{2}-\frac{\left(\sum\left(n_{i}-3\right) z_{i}\right)^{2}}{\sum\left(n_{i}-3\right)},
$$

Where $i$ goes from 1 to 3 for 3 correlations, $n_{i}$ is a number of observations used to obtain each correlation. $z_{i}=\frac{1}{2} \ln \left(\frac{1+r}{1-r}\right)$ is Fisher transformed value of correlation, which is based on Pearson's correlation. In order to work with a situation when assumptions of Pearson's correlation can be violated, we first obtain Kendal's tau and then calculate $\mathrm{r}$ from Kendal's tau using formula provided in [60]: $r=\sin (0.5 \times \pi \times \operatorname{tau})$. 

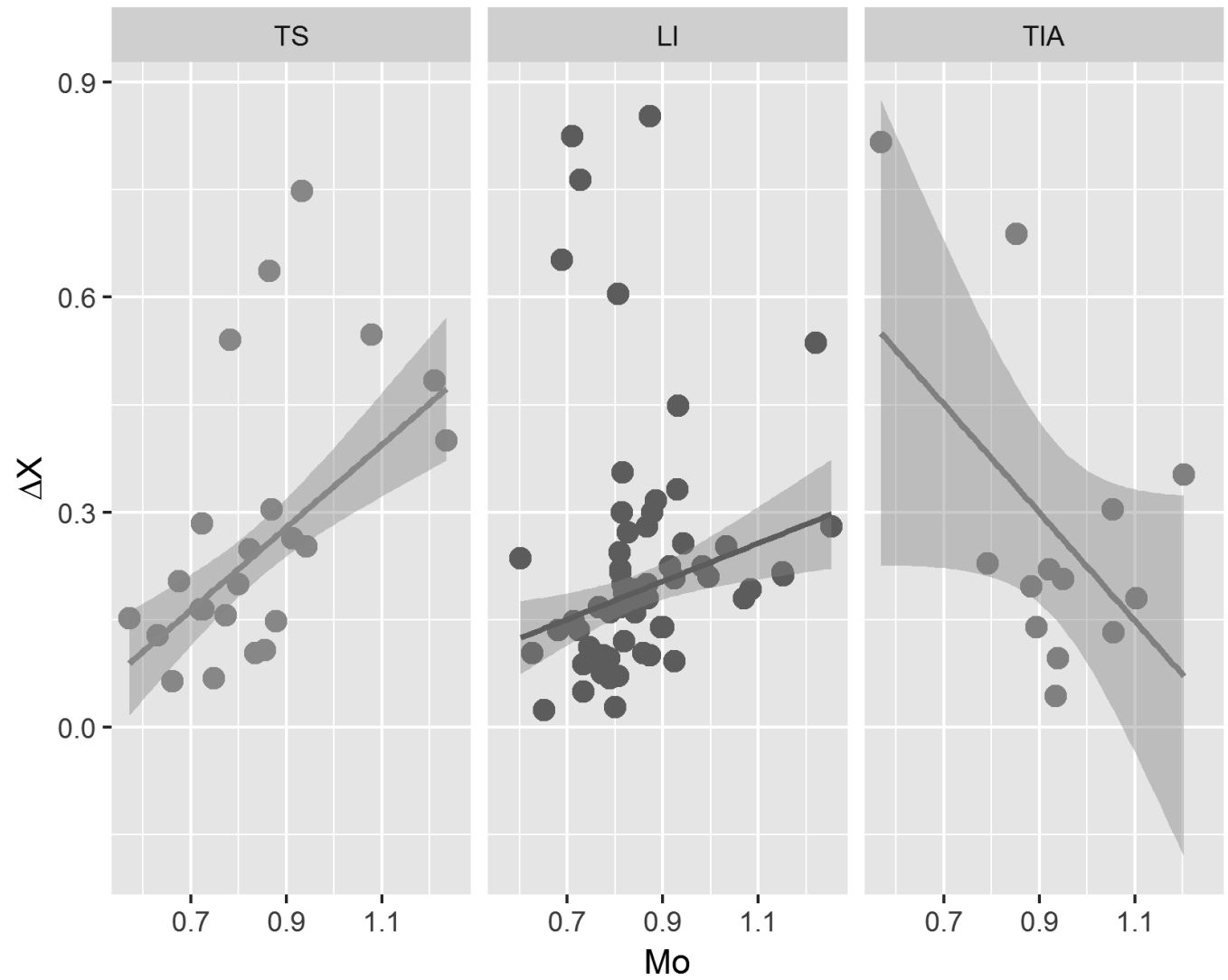

Fig. 2. Scatter plot for $\Delta \mathbf{X}$ vs MO

Separated by categories TS, LI, TIA. Robust regression with M-estimator is used for determining a regression line. Gray area represents a $95 \%$ confidence interval.
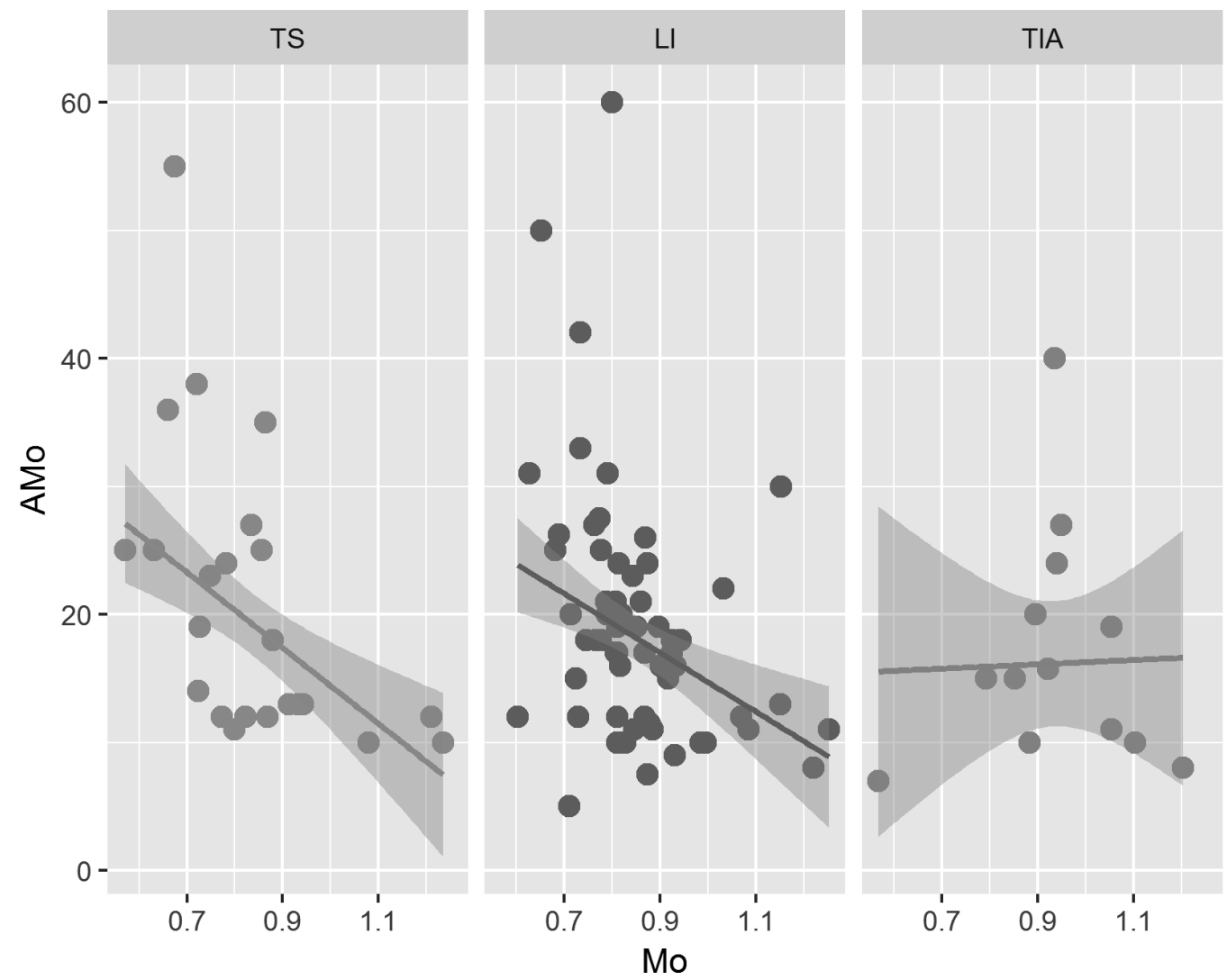

Fig. 3. Scatter plot for AMO vs MO

Separated by categories TS, LI, TIA. Robust regression with M-estimator is used for determining a regression line. Gray area represents a $95 \%$ confidence interval. 
Table 2. Regression coefficients of the dependence between $\Delta X$ and Mo in patients with TIA, LS, and TS on the $1^{\text {st }}$ day of admission

\begin{tabular}{||c|c|c|c|c|c|c|c|c|c||}
\hline \hline $\mathbf{( 1 ) - ( 2 )}$ & $\mathbf{n ~ ( 1 , 2 )}$ & $\mathbf{r}(\mathbf{1}, \mathbf{2})$ & $\mathbf{r} \mathbf{( 2 )}$ & $\mathbf{r ( 1 ) - r ( 2 )}$ & fisher $\mathbf{z}$ & Zou $\mathbf{c ~ i}$ & $\mathbf{p}$ value & $\mathbf{p}$ value adjusted & Signif \\
\hline TIA-TS & 13,23 & -0.317 & 0.593 & -0.909 & -2.608 & $(-1.4,-0.21)$ & 0.009 & 0.027 & $*$ \\
\hline TIA-LI & 13,61 & -0.317 & 0.384 & -0.701 & -2.140 & $(-1.2,-0.05)$ & 0.032 & 0.065 & \\
\hline TS-LI & 23,61 & 0.593 & 0.384 & 0.209 & 1.069 & $(-0.20,0.53)$ & 0.285 & 0.285 & \\
\hline
\end{tabular}

Obtained p-value for "AMo vs Mo" is 0.075 , and for " $\Delta \mathrm{X}$ vs Mo" is 0.032 . Thus, we will continue to look for a difference in correlations only for " $\Delta \mathrm{X}$ vs Mo" case. In order to do this, we will use Fisher's statistics calculation and Zou confidence interval calculation implemented in "cocor.indep.groups" function of a cocor package (details can be found in [53]). Again, all this is done with $\mathrm{r}$ correlation obtained from Kendal's tau as above. Finally, p-values are adjusted using Holm's method. As you can see in the Table 2, only TIA-TS shows a statistically significant difference.

\section{Additional exploration}

In addition to the results above, we performed an exploration study of correlations between parameters of ANS and clinical status in TIA patients (using Kendall's tau statistics). In this case we use data collected for all patients admitted and surveyed in the Stroke Unit of the Gomel Regional Veteran's Hospital from 2010 to 2016: TIA patients (31 women and 20 men, mean age $62.6 \pm 1.6$ years), 71 patients with LS (38 women and 33 men, mean age $53.4 \pm 1.8$ years) and 25 patients with TS (11 women and 14 men, mean age 51.1 \pm 3.3 years), all patients are of Caucasian race. On the $1^{\text {st }}$ day, NIHSS estimation was $5(4 ; 7)$ for LS, and $13(9.5 ; 17)$ for TS. TIA patients at admission had the following neurological deficit: hemiparesis 55\%, asymmetry of nasolabial folds $67 \%$, instability in the Romberg position $63 \%$, asymmetry of tendon reflexes $78 \%$ and Babinski symptom $82 \%$, hypoesthesia $33 \%$, aphasia $12 \% . \mathrm{ABCD}^{2}$ estimation in TIA patients was $4(3 ; 5.3)$. Co-morbidities in TIA and stroke patients are presented in Table 3.

Paresis is the most common symptom of stroke and TIA. In TIA patients, positive correlation between the hemiparesis level and AMo value on the $1^{\text {st }}$ day of admission was found: $r=0.6 ; p=0.002$. Positive dependence of these parameters reflects a negative role of sympathicotonia in TIA patients. This data agrees with previously published results stating that sympathetic AMo index value may be connected to the degree of hemiparesis in stroke

Table 3. Co-morbidities in TIA and stroke patients (in \%)

\begin{tabular}{|l|c|c|c||}
\hline \hline Co-morbidity & TIA & LS & TS \\
\hline Hypertension & 90 & 30 & 8 \\
\hline Coronary heart disease & 62 & 21 & 8 \\
\hline Myocardial infarction & - & - & - \\
\hline Diabetes mellitus & 4 & 9 & 20 \\
\hline Chronic cerebral insufficiency & 4 & 6 & 16 \\
\hline
\end{tabular}

patients [7, 24-27, 40]. There has been found a dependence between motor function disturbance and Mo $(\mathrm{r}=-0.44 ; \mathrm{p}=0.016)$ in TIA patients which agrees with an expectation, that humoral regulation determines the status of the ANS regulation of the stress response in stroke patients [45]. We have not found a correlation between the hemiparesis level and $\Delta \mathrm{X}$ value $(\mathrm{r}=-0.2 ; \mathrm{p}=0.3)$. Correlation between parameters of the sympathetic part of the $\mathrm{ANS}$ and $\mathrm{ABCD}^{2}$ score was found to be low and has low statistical significance (AMo $\mathrm{r}=0.37 ; \mathrm{p}=0.065$ ) in TIA patients. The association between parasympathetic $\Delta \mathrm{X}$ and $\mathrm{ABCD}^{2}$ score $(\mathrm{r}=-0.07 ; \mathrm{p}=0.74)$ and $\mathrm{Mo}$ and $\mathrm{ABCD}^{2}$ score $(r=-0.04 ; p=0.83)$ is statistically insignificant as well.

\section{CONCLUSIONS}

We failed to reject the null hypothesis for a difference in correlations between AMo and Mo, in all the cases of brain ischemia. For the difference in correlations between $\Delta \mathrm{X}$ and Mo, the null hypothesis was rejected in patients with TIA and TS. Such difference in correlations between $\triangle \mathrm{X}$ and Mo in TIA and TS patients is a key to understanding the difference between TIA and stroke pathogenesis.

Based on the above obtained results, we propose the following hypothesis. The highest activity of the sympathetic part of the ANS in patients with TIA is caused not only by an increase in sympathetic activity in response to the increase in hormonal influence (Fig. 1). It is also caused by the absence of an increase in activity of the parasympathetic part of the ANS in the same conditions (Fig. 2). This distinguishes TIA group from the Stroke group. We believe this would be important to plan and conduct a study addressing this.

Exploratory analysis revealed several possibly significant correlations including hemiparesis level and AMo, motor function disturbance and Mo in patients with TIA. This could indicate the negative role of the increased sympathetic activity in TIA patients, which is similar to the case of stroke patients. At the same time, a low correlation between $\mathrm{AMo}$ and $\mathrm{ABCD}^{2}$ might indicate that an increase of the sympathetic activity in TIA patients has low influence to short-term prognosis of the stroke.

\section{ACKNOWLEDGMENTS}

The study was supported by a grant of the Belarusian Foundation for Basic Research (M13-081). We are grateful to Dr. Yuliya Samsonava for language editing. 


\section{COMPETING INTERESTS}

Authors have declared that no competing interests exist.

\section{AFFILIATIONS}

Natallia V. Halinouskaya, PhD, MD, Gomel State Medical University, Gomel, Belarus.

Sergey V. Samsonau, PhD, Princeton International School of Mathematics and Science, Princeton, NJ, USA.

\section{References}

1. Jauch EC, Saver JL, Adams HP, Bruno A, Connors JJ, Demaerschalk BM, et al. Guidelines for the early management of patients with acute ischemic stroke: a guideline for healthcare professionals from the American Heart Association/American Stroke Association. Stroke 2013; 44: 870-947. https://doi.org/10.1161/STR.0b013e318284056a

2. Lager KE, Mistri AK, Khunti K, Haunton VJ, Sett AK, Wilson $\mathrm{AD}$. Interventions for improving modifiable risk factor control in the secondary prevention of stroke. In: Lager KE, editor. Cochrane Database of Systematic Reviews. Chichester, UK: John Wiley \& Sons, Ltd, 2014.

3. Likhachev S, Astapenka A, Belyavsky N. Transient ischemic attack: etiology, pathogenesis, classification, clinic, diagnostics. Med News 2003; 10: 31-7.

4. Gonchar IA, Likhachev SA, Frolov AV, Gul LM, Prudyvus IS, Ved GKN. The heart rate variability in the acute lacunar cerebral infarct. J Neurol Psychiatry 2011; 8: 15-20.

5. Fonyakin A, Samochvalova EV, Geraskina L. Vegetative regulation of the heart and risk of cardiac complications in ischemic stroke. Pract Angiol 2008; 5: 26.

6. Laowattana S, Zeger SL, Lima JAC, Goodman SN, Wittstein IS, Oppenheimer SM. Left insular stroke is associated with adverse cardiac outcome. Neurology 2006; 66: 477-83. https://doi.org/10.1212/01.wnl.0000202684.29640.60

7. Sander D, Winbeck K, Klingelhöfer J, Etgen T, Conrad B. Prognostic relevance of pathological sympathetic activation after acute thromboembolic stroke. Neurology 2001; 57: 833-8. https://doi.org/10.1212/WNL.57.5.833

8. Xiong L, Leung H, Chen XY, Han JH, Leung T, Soo Y, et al. Preliminary findings of the effects of autonomic dysfunction on functional outcome after acute ischemic stroke. Clin Neurol Neurosurg 2012; 114: 316-20. https://doi.org/ 10.1016/j.clineuro.2011.10.037

9. Bassi A, Colivicchi F, Santini M, Caltagirone C. Cardiac autonomic dysfunction and functional outcome after ischaemic stroke. Eur J Neurol 2007; 14: 917-22. https://doi.org/ 10.1111/j.1468-1331.2007.01875.x

10. Chen P-L, Kuo TBJ, Yang CCH. Parasympathetic activity correlates with early outcome in patients with large artery atherosclerotic stroke. J Neurol Sci 2012; 314: 57-61. https://doi.org/10.1016/j.jns.2011.10.034

11. De Raedt S, De Vos A, De Keyser J. Autonomic dysfunction in acute ischemic stroke: an underexplored therapeutic area? J Neurol Sci 2015; 348: 24-34.

12. Palavra F, Reis F, Marado D, Sena A. Biomarkers of cardiometabolic risk, inflammation and disease. New York, London: Springer Intern. Publ., 2015; 172.

13. Gontschar I, Stepanova U, Prudivus I. Biochemical predictors and markers of stroke. 1st ed. Minsk: BelMAPO, 2013.
14. Banu I, Nguyen MT, Hamo-Tchatchouang E, Cosson E, Valensi P. Relationship between blood pressure, heart rate and cardiac autonomic dysfunction in non-diabetic obese patients. Ann Cardiol Angeiol (Paris) 2015; 64: 139-44. https://doi.org/10.1016/j.ancard.2015.04.021

15. Fox K, Bousser M-G, Amarenco P, Chamorro A, Fisher M, Ford I, et al. Heart rate is a prognostic risk factor for myocardial infarction: A post hoc analysis in the PERFORM (Prevention of cerebrovascular and cardiovascular Events of ischemic origin with teRutroban in patients with a history oF ischemic strOke or tRansient isc. Int J Cardiol 2013; 168: 3500-5. https://doi.org/10.1016/j.ijcard.2013.04.206

16. Korkmaz ME, Müderrisoğlu H, Uluçam M, Ozin B, Drewiecki J, Giec L, et al. Effects of spironolactone on heart rate variability and left ventricular systolic function in severe ischemic heart failure. Am J Cardiol 2000; 86: 649-53. https://doi.org/10.1016/S0002-9149(00)01046-8

17. Kurata C, Uehara A, Sugi T, Ishikawa A, Fujita K, Yonemura $\mathrm{K}$, et al. Cardiac autonomic neuropathy in patients with chronic renal failure on hemodialysis. Nephron 2000; 84: 312-9. https://doi.org/10.1159/000045605

18. Kurata C, Uehara A, Ishikawa A. Improvement of cardiac sympathetic innervation by renal transplantation. J Nucl Med 2004; 45: 1114-20.

19. Manzella D, Paolisso G. Cardiac autonomic activity and Type II diabetes mellitus. Clin Sci 2005; 108: 93-9. https://doi.org/10.1042/CS20040223

20. Mortara A, La Rovere MT, Pinna GD, Maestri R, Capomolla S, Cobelli F. Nonselective beta-adrenergic blocking agent, carvedilol, improves arterial baroflex gain and heart rate variability in patients with stable chronic heart failure. J Am Coll Cardiol 2000; 36: 1612-8. https://doi.org/ 10.1016/S0735-1097(00)00900-1

21. Nagata K, Sasaki E, Goda K, Yamamoto N, Sugino M, Yamamoto K, et al. Differences in heart rate variability in non-hypertensive diabetic patients correlate with the presence of underlying cerebrovascular disease. Clin Physiol Funct Imaging 2006; 26: 92-8. https://doi.org/10.1111/ j.1475-097X.2006.00654.x

22. Vinik AI, Maser RE, Mitchell BD, Freeman R. Diabetic autonomic neuropathy. Diabetes Care 2003; 26: 1553-79. https://doi.org/10.2337/diacare.26.5.1553

23. Bolis L, Licinio J, Govoni S. Handbook of the autonomic nervous system in health and disease. New York : Dekker, 2003; 667.

24. Kwon D-Y, Lim HE, Park MH, Oh K, Yu S-W, Park K-W, et al. Carotid atherosclerosis and heart rate variability in ischemic stroke. Clin Auton Res 2008; 18: 355-7. https://doi.org/10.1007/s10286-008-0502-z

25. Meyer S, Strittmatter M, Fischer C, Georg T, Schmitz B. Lateralization in autonomic dysfunction in ischemic stroke involving the insular cortex. Neuroreport 2004; 15: 357-61. https://doi.org/10.1097/00001756-200402090-00029

26. Xiong L, Leung HW, Chen XY, Leung WH, Soo OY, Wong KS. Autonomic dysfunction in different subtypes of post-acute ischemic stroke. J Neurol Sci 2014; 337: 141-6. https://doi.org/10.1016/j.jns.2013.11.036

27. Xiong L, Leung HW, Chen XY, Han JH, Leung WH, Soo OY, et al. Autonomic dysfunction in ischemic stroke with carotid stenosis. Acta Neurol Scand 2012; 126: 122-8. https://doi.org/10.1111/j.1600-0404.2011.01617.x

28. Xiong L, Leung HHW, Chen XY, Han JH, Leung TWH, Soo YOY, et al. Comprehensive assessment for autonomic dysfunction in different phases after ischemic stroke. 
Int J Stroke 2013; 8: 645-51. https://doi.org/10.1111/ j.1747-4949.2012.00829.x

29. Kazakov V, Snegir M, Snegir A. Passways of interaction of nervous, endocrine and immune systems in the regulation of body functions. Arch Clin Exp Med 2004; 13: 3-10.

30. Dutsch M, Burger M, Dorfler C, Schwab S, Hilz MJ. Cardiovascular autonomic function in poststroke patients. Neurology 2007; 69: 2249-55. https://doi.org/10.1212/ 01.wnl.0000286946.06639.a7

31. Fonyakin A, Geraskina L, Samokhvalova E. Dynamics of indices of heart rate variability in the acute period of ischemic stroke. Cardiovasc Ther Prev 2008; 7: 386.

32. Graff B, Gąsecki D, Rojek A, Boutouyrie P, Nyka W, Laurent $S$, et al. Heart rate variability and functional outcome in ischemic stroke. J Hypertens 2013; 31: 1629-36. https://doi.org/10.1097/HJH.0b013e328361e48b

33. Bozluolcay M, Ince B, Celik Y, Harmanci H, Ilerigelen B, Pelin Z. Electrocardiographic findings and prognosis in ischemic stroke. Neurol India 2003; 51: 500-2.

34. Boselli C, Gioglio L, Preda S, Govoni S. Selective impairment of noradrenergic transmission in the bisected rat vas deferens following photochemically-induced cerebral ischaemia. Int J Androl 2007; 30: 129-36. https://doi.org/ 10.1111/j.1365-2605.2006.00719.x

35. Sycheva M, Astrakov S, Kuryachenko YT, Porotnikova NA, Oleksyuk N. Effect of the neurovegetative blockade on haemodinamic parameters and the course of acute period of stroke. Bull Sib Med 2009; 3: 39-43.

36. Jiang Q, Gingles NA, Olivier MA, Miles LA, Parmer RJ. The anti-fibrinolytic SERPIN, plasminogen activator inhibitor 1 (PAI-1), is targeted to and released from catecholamine storage vesicles. Blood 2011; 117: 7155-63. https://doi.org/ 10.1182/blood-2010-05-287672

37. Ozdemir O, Soylu M, Alyan O, Geyik B, Demir AD, Aras D, et al. Association between mean platelet volume and autonomic nervous system functions: Increased mean platelet volume reflects sympathetic overactivity. Exp Clin Cardiol 2004; 9: 243-7.

38. Capes SE, Hunt D, Malmberg K, Pathak P, Gerstein HC. Stress hyperglycemia and prognosis of stroke in nondiabetic and diabetic patients: a systematic overview. Stroke 2001; 32: 2426-32. https://doi.org/10.1161/hs1001.096194

39. von Känel R, Dimsdale JE. Effects of sympathetic activation by adrenergic infusions on hemostasis in vivo. Eur $\mathrm{J}$ Haematol 2000; 65: 357-69. https://doi.org/10.1034/ j.1600-0609.2000.065006357.x

40. Halinouskaya N, Smychek V, Latischeva V, Usava N, NV B. Relationship between vegetative status and stroke severity Probl Heal Hum Ecol 2012; 1: 92-7.

41. Halinouskaya N, Usava N. The comparative analysis of the vegetative status in patients with passing and proof forms of the ischemic brain damage. Neurol Neurosurg West Eur 2012; 1 : 43-51.

42. Smychek V, Halinouskaya N, Usava N, Elisavetay P, Ivanjkov K. Features of the vegetative status in patients with the stroke in comparison with conditions-predictors. International Neurol J 2012; 4: 54-9.

43. Smychek VB, Halinouskaya NV, Latisheva VY, Usava NN, Vasilcanka NV, Shaparava MV. The analysis of the psychovegetative status in patients with ischemic injury of the brain. Natl J Neurol 2012; 2: 76-81.

44. Halinouskaya N, Usava N, VJ L. The comparative analysis of the psychovegetative status in young patients with ischemic and autoimmune brain damage. Med Panor 2010; 11:28-32.
45. Halinouskaya NV, Samsonau SV, Usava NN, Smychek VB. Thyroid hormone status in stroke and transient ischemic attack patients. Neurol Semin 2015; 19: 207-9.

46. Easton JD, Saver JL, Albers GW, Alberts MJ, Chaturvedi S, Feldmann E, et al. Definition and evaluation of transient ischemic attack. Stroke 2009; 40: 2276-93. https://doi.org/ 10.1161/STROKEAHA.108.192218

47. Rothwell P, Giles M, Flossmann E, Lovelock C, Redgrave J, Warlow $\mathrm{C}$, et al. A simple score (ABCD) to identify individuals at high early risk of stroke after transient ischaemic attack. Lancet 2005; 366: 29-36. https://doi.org/10.1016/ S0140-6736(05)66702-5

48. Baevsky R. Analysis of heart rate variability with the use of various electrocardiographic systems. Vestn Arythmology 2001; 24: 65-87.

49. Jemaitite D, Teljknis L. Heart rate variability. Vilnius: Mokslas, 1992; 130.

50. Malik M, et al. Guidelines heart rate variability. Standards of measurement, physiological interpretation, and clinical use. Eur Hear J Electrophysiol Oct 1996; 17: 354-81.

51. Cygankiewicz I, Zareba W. Heart rate variability. Handb Clin Neurol 2013; 117: 379-93. https://doi.org/10.1016/ B978-0-444-53491-0.00031-6

52. R Core Team. R: a language and environment for statistical computing. 2017.

53. Diedenhofen B, Musch J. cocor: a comprehensive solution for the statistical comparison of correlations. PLoS One 2015; 10: e0121945.

54. Wickham H. ggplot2: elegant graphics for data analysis. New York: Springer-Verlag, 2009.

55. Wickham H. tidyverse: easily install and load "Tidyverse" packages. 2017

56. Wickham H. stringr: simple, consistent wrappers for common string operations. 2017.

57. Venables WN, Ripley BD. Modern applied statistics with S. Fourth. New York: Springer, 2002.

58. Alma ÖG. Comparison of robust regression methods in linear regression. Int J Contemp Math Sci 2011; 6: 409-21.

59. Levy KJ. A multiple range procedure for independent correlations. Soc Sci Res 1974; 3: 89-93. https://doi.org/10.1016/ 0049-089X(74)90022-2

60. Walker DA. JMASM9: converting Kendall's Tau for correlational or meta-analytic analyses. J Mod Appl Stat Methods 2003; 2: 525-30. https://doi.org/10.22237/jmasm/ 1067646360

\section{N. V. Halinouskaya, S. V. Samsonau}

\section{PRAEINANTI SMEGENU IŠEMIJOS PRIEPUOLI IR INSULTĄ PATYRUSIŲ PACIENTŲ AUTONOMINEં BŪKLE்}

\section{Santrauka}

Ivadas. Pristatomo tyrimo tikslas buvo įvertinti autonominès nervų sistemos (ANS) būklę dviejose pacientų grupèse 10 dienų ūminiu laikotarpiu. Pirmajai grupei buvo priskirti pacientai, patyrę praeinanti išemijos priepuoli (PSIP), o antrajai - pacientai, patyrę įvairaus sunkumo galvos smegenų infarktą (GSI)

Tyrimo metodika. Perspektyvinis kohortinis tyrimas atliktas Gomelio valstybinio medicinos universiteto Neurologijos ir neurochirurgijos klinikos Gomelio apskrities veteranų ligoninès insulto poskyryje $2014 \mathrm{~m}$. gegužès - $2016 \mathrm{~m}$. kovo mèn. I PSIP grupę itraukta 13 pacientu, o ị GSI - 84 pacientai, iš kurių 61 pa- 
ciento išemijos zona (infarkto židinys) buvo mažesnè nei $15 \mathrm{~mm}$ (lakūninis insultas - LI) ir 23 - didesnè nei $15 \mathrm{~mm}$ (pilnas insultas - PI). ANS vertinimo žymeniu pasirinktas širdies susitraukimų dažnis (ŠSD), matuotas pirmą ir dešimtą hospitalizacijos po galvos smegenų kraujotakos sutrikimo dienomis. Širdies susitraukimų dažnio kintamumas vertintas naudojant šiuos keturis kriterijus: SDNN (standartinis normalaus R-R intervalo nuokrypis milisekundėmis (ms)), $\Delta \mathrm{X}$ (maksimalaus ir minimalaus $\mathrm{R}-\mathrm{R}$ intervalo skirtumas ms), Mo (R-R intervalų trukmès režimas $\mathrm{ms}$ ), AMo (R-R intervalų trukmès režimo amplitudè procentais).

Rezultatai. Vertinant pirmają dieną išmatuoto ŠSD priklausomybę tarp $\Delta \mathrm{X}$ (apibūdina ANS parasimpatinès dalies aktyvu- mą) ir Mo (apibūdina ANS simpatinès dalies aktyvumą) rodiklių, rastas statistiškai reikšmingas skirtumas tarp PSIP ir PI grupių $(\mathrm{p}=0,01)$.

Išvados. Esminis skirtumas tarp PSIP ir PI yra pirmosios dienos humoralinio ANS aktyvumo ir parasimpatinès sistemos tarpusavio ryšys, kuris nulemia specifines praeinančio smegenų išemijos priepuolio patogenezès ypatybes.

Raktažodžiai: praeinantis galvos smegenų išemijos priepuolis, lakūninis insultas, totalus insultas, simpatinè ir parasimpatinė autonominės nervų sistemos dalys.

Gauta:

Priimta spaudai:

20180511 